\title{
Nigerian Copyright Reform and Implications for Access to Teaching and Learning Materials (TLMs) in the Digital Age
}

\section{Helen Chuma-Okoro}

Research Fellow, Nigerian Institute of Advanced Legal Studies (NIALS), Lagos

\begin{abstract}
This article examines the extent to which the provisions of Nigeria's draft Copyright Bill promote access to teaching and learning materials (TLMs), with such access framed as an important public interest goal. The article highlights the weaknesses in the extant Nigerian copyright statute with regard to TLM access, and examines the extent to which the provisions of the draft Bill would provide improvement. The article concludes that while the draft Bill provides significant improvements in respect of TLM access, it also contains significant weaknesses and gaps which Nigerian lawmakers should seek to address.
\end{abstract}

\section{Keywords}

copyright, access, teaching and learning materials (TLMs), public interest, access to knowledge (A2K), Nigeria, Copyright Act, draft Copyright Bill

DOI: https://doi.org/10.23962/10539/26172

\section{Recommended citation}

Chuma-Okoro, H. (2018). Nigerian copyright reform and implications for access to teaching and learning materials (TLMs) in the digital age. The African Journal of Information and Communication (AJIC), 22, 1-28. https://doi.org/10.23962/10539/26172

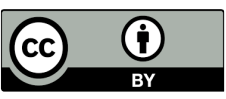

This article is licensed under a Creative Commons Attribution 4.0 International (CC BY 4.0) licence: http://creativecommons.org/licenses/by/4.0 


\section{Introduction}

The concern for access to teaching and learning materials (TLMs) is closely related to copyright law and how it impacts human wellbeing. It is also a critical part of the larger concern for access to knowledge (A2K), which is strongly affected by intellectual property rights, including copyright (see, for example, Armstrong et al., 2010; Krikorian \& Kapczynski, 2010). ${ }^{1}$ This has to do with the natural tendency of copyright to restrict access to protected subject matter in the absence of appropriate legal safeguards (Kapczynski, 2010, pp. 23-24)-i.e., in the absence of appropriate copyright limitations and exceptions. It has been argued that for most developing countries, "A2K has much to offer towards economic development in the form of improving access to learning materials, which constitute the basic resources of education" (Jonker, 2009, p. 1).

Education is not only integral to sustainable development (Brende, 2015; UN, 2011), but has long been recognised as a fundamental human right that should not be taken for granted (UN General Assembly, 1948; UN Convention on the Rights of the Child, 1989; UNESCO, 2005).More recently, the post-2015 Development Agenda has emphasised the need for governments to ensure "inclusive and equitable quality education" and to "promote lifelong learning opportunities for all" as an important strategy in attaining the Sustainable Development Goals (SDGs) (NPC, 2009; UNESCO, 2000; UNESCO, 2017, p. 6; UNESCO \& UNICEF, 2013). TLMs are important resources for achieving quality education, including not only physical access to education but also, and more importantly, the content of what people learn (UNESCO \& UNICEF, 2013, p. 22). Naturally, the content is directly affected by the quality of TLMs in use; poor-quality resources would result in poor knowledge and high quality materials would enhance knowledge.

Education is an important part of the Nigerian government's responsibility for its citizens both as a right and as an important policy matter. The Nigerian government has a legal responsibility to provide free, quality and compulsory basic education to every Nigerian child up to junior secondary level (Adesomoju, 2017). ${ }^{2}$ This is in addition to a strong policy objective, as provided in section 18(1) of Nigeria's Constitution, to provide "equal and adequate educational opportunities at all levels". As a developing country, access to TLMs in Nigeria is strategic to the achievement of these objectives and the many education milestones in line with international standards and the ensuing obligations on countries to implement them. The timeframe for the achievement of the education agenda of the UN Millennium Development Goals (MDGs), which called on every country to ensure full primary

1 Out of this concern has emerged the A2K movement.

2 See section 2(1) of the Compulsory, Free Universal Basic Education (UBE) Act, 2004, and section 15 of the Child's Rights Act, 2003. See also Adesomoju (2017), and The Registered Trustees of the SocioEconomic Rights \& Accountability Project (SERAP) v The Federal Government of Nigeria E Another, Suit No: ECW/CCJ/APP/12/07. 
education for every child by the year 2015 may have expired, but the education project in the post-2015 development Agenda no doubt extends and reshapes the MDGs for sustainable development. The Nigerian education structure comprises both formal and informal education programmes for both youths and adults up to tertiary levels, in addition to the basic primary levels (Federal Republic of Nigeria, 2013). This has been fashioned with a clear objective of aligning education delivery with global trends and in response to the responsibility of government to ensure quality education at all levels for its citizens (Federal Ministry of Education, 2015). However, a rapidly growing population increases demand for education beyond capacity at all levels, leaving out large numbers of unserved prospective learners (IOM, 2014, pp. 18-22; Moja, 2000). Poverty creates further barriers for many who cannot afford the costs of quality education, including the cost of TLMs required by both teachers and learners for their respective needs (Onwurah \& Chiaha, 2007).

Like in other African countries, many Nigerians face serious handicaps in accessing TLMs to meet their education needs (Federal Ministry of Education, 2015; Moja, 2000). While some research has been conducted on factors hindering access to quality education in Nigeria, not much has been said about the role of copyright in creating barriers to access to TLMs in Nigeria. Instead, inaccessibility of TLMs in Nigeria has been attributed mainly to unavailability in their required formats or content, coupled with the absence of a vibrant local industry for the production of the required materials and high cost of importing them (Federal Ministry of Education, 2015, p. 42; Moja, 2000). Lack of expert assistance and technical support, and inability to keep abreast with current innovative developments, are some of the factors that have been identified as hindrances to the ability of teachers to improvise instructional materials, with matters of copyright not highlighted (Olibie et al., 2013).

The Nigerian copyright system is largely ineffective in controlling infringement of protected works (Oguamanam, 2011; Solanke, 2014). Thus, it could be argued that the real impact of copyright on access, which could arise from challenges in obtaining copyright clearances for the use of work, has hardly been felt. Yet, as digital technology becomes increasingly pervasive, it is inevitable that concerns over copyright-induced barriers to access, which currently dominate the discourse on A2K at the global level, will become resonant in Nigeria. The increasing presence of digital content and digital platforms in all spheres of human endeavour in the country, including education, makes it almost inevitable that the copyright regime will eventually become a critical factor in ensuring access to TLMs. By its nature, digital technology transforms the manner of production, dissemination and storage of data. As such, the traditional safeguards and balance that have shaped copyright systems since inception, with a strong concern for access to copyright materials, have been threatened in ways that also affect access to TLMs (National Research Council, 2000). Copyrighted materials in digital form can be easily duplicated, but at the same time, access to these materials is now being protected with digital locks and licences, 
some of which impose protection standards in excess of minimum standards set out in copyright laws.

There is no doubt that copyright-induced barriers to knowledge access are relevant to Nigeria, given its status as a developing country, on the disadvantaged side of the digital divide, with much reliance on foreign-owned knowledge assets (Hongladarom, 2007; IOM, 2014). A prominent access to knowledge challenge, which also affects Nigeria, is the cost of obtaining licences for the use of copyrighted foreign works, especially materials in digital formats (CIPR, 2002, p. 96). Alternatively, producing TLMs locally requires incentives for the local industry (Oye et al., 2011). Copyright is traditionally intended to provide such incentives, albeit with the undesirable consequence of imposing a burden on access. As the UK's 2002 CIPR report noted,

[t]he crucial issue for developing countries is getting the right balance between protecting copyright and ensuring adequate access to knowledge and knowledge-based products. This concern remains and particularly so for developing countries by the extension of copyright to software and to digital material. (CIPR, 2002, p. 96; see Adewopo, 2012, p. 16)

Presently, Nigeria is on the threshold of amending its Copyright Act of 1988 (hereafter the "Act"), which was enacted before the current issues arising from digital technology began to strongly manifest themselves. In late 2015, the Nigerian Copyright Commission (NCC) published the draft Copyright Bill (hereafter the "draft Bill"), but it is yet to be enacted into law. The NCC submitted the draft Bill to the Federal Executive Council (FEC) in 2017, and the NCC reported in June 2018 that the FEC has approved the Bill as "the 2017 Draft Bill". ${ }^{3}$ The next stage will be presentation in the National Assembly to begin the process of passage into law.

This article provides an overview of the current Copyright Act provisions on access to TLMs, and outlines its inherent weaknesses in fostering access to TLMs in the digital age. The article also examines the extent to which the provisions of the draft Bill would, if passed into law, improve access to TLMs, and some elements of the draft Bill requiring reconsideration. I seek to identify what must be retained, what should be reviewed, and what should be removed, in the draft Bill in order to foster TLM access. In the process, the article explores the meaning of access in the context of TLMs; the role of copyright; and the implications of digital technology on both copyright and access to TLMs.

3 Information based on the author's email and telephonic communications in 2017 with Michael Akpan, Deputy Director, Regulatory Department, Nigerian Copyright Commission (NCC); and on the NCC's 29 June 2018 (NCC, 2018) announcement on its website. 


\section{Copyright and access to TLMs}

The term TLMs may have context-specific meanings, depending on the subject in question. ${ }^{4}$ But basically, the term refers to materials used for training and educational purposes in various settings. According to UNESCO, "teaching materials" are "aids used by trainers to help them in teaching their lessons effectively", and "learning materials" are those "used by learners/trainees to help them learn effectively" (Chanda et al., n.d., p. 2). TLMs cover a spectrum of materials in expressive formats, including articles, books, charts, pictures, diagrams and videos (Chanda et al., n.d., p. 4). This implies that TLMs could fall under any of the categories of protectable subject matter of copyright law, which generally protects expressive contents in the category of literary, artistic, dramatic, musical and scientific works (Berne Convention, Art. 2). In the digital era, these materials could be presented in print or digital formats, and include software.

TLMs can either be produced locally or sourced from outside the country. Either way, access is crucial as TLM producers generally rely on materials from other sources to develop new ones or to adapt existing ones to local needs (Chanda et al., n.d., pp. 3-5). However in the context of TLMs, access entails more than availability. It also goes beyond ownership of the materials and extends "to ways in which learners make use of texts" and other materials for their educational requirements (Rens et al., 2006, p. 6). Access therefore means that TLMs must be available, affordable, reliable and relevant to local needs (UNESCO, 2000, pp.13, 28-29). They must be available in an inclusive range of languages, and in formats suitable for use by anyone, including the print disabled (Chanda et al., n.d.). A material, e.g., a book, in the possession of a teacher or learner that is written in a language not understood by the teacher or learner does not constitute access.

The relationship between access to TLMs and copyright law is connected to the fact that TLMs constitute a range of materials normally protected under copyright law as works of expression. ${ }^{5}$ As the CIPR report observed, "software, textbooks, and academic journals are key items where copyright is a determining factor in pricing and access, and which are also essential ingredients in education" (CIPR, 2002, p. 17). Concerns over the impact of copyright on access to TLMs derive from the very nature of copyright as a bundle of legal entitlements granting work owners the power to exclusively control most uses of their work. Therefore, use of the copyrightprotected work by the public is subject to the consent of the copyright owner, usually at a cost to the intended user, and any use without the required consent amounts to

\footnotetext{
4 They are often grouped together and referred to as educational resources or "learning materials". 5 According to the Berne Convention, "literary and artistic works" include books, pamphlets, lectures, dramatic works, musical compositions, drawing, painting, architecture, and others. The WTO Agreement on Trade-Related Aspects of Intellectual Property Rights (TRIPS Agreement) extends the scope of copyright subject matter to computer programs and databases. See Articles 1 and 2 of the Berne Convention, and Article 10 of the TRIPS Agreement.
} 
an infringement of the copyright (Lewinski, 2008). Although based on the wellintended objectives of incentivising creation, and facilitating dissemination, of works (Hughes, 1988), copyright can potentially restrict access to the subject matter under protection where the required consent cannot be easily obtained. In the case of TLMs, such barriers may affect activities like copying, reproducing the work in formats that are suitable for the potential users, and sharing or using the work to create new materials. These are acts generally reserved exclusively for owners of copyright and which require owners' consent for a third party to carry out any of these acts. They are, at the same time, activities that often occur indiscriminately within an education or learning environment.

Copyright law has always, since its onset, included recognition of the objective of ensuring public-interest access to works. Perambulatory provisions in copyright's mother statute, the Statute of Anne of 1710, underscores the fact that one of copyright's primary aims is to encourage the diffusion of knowledge "for the purpose of learning". Standard provisions in current copyright statutes that require the deposit of copies of copyrighted works in public libraries were inaugurated at that time, and clearly intended to encourage access to books for public use, particularly where university libraries were concerned. Sections 4 and 5 of the Statute of Anne required copies of books to be deposited with libraries of important academic institutions for their use-in recognition of the strategic role of libraries in promoting access to TLMs. Libraries, and other cultural institutions such as museums and archives-as "gateways to knowledge and culture"-facilitate access to knowledge resources by the public (White, 2012). They collate, preserve and lend out knowledge resources to users for their needs; and also provide on-site access to their resources. In the learning environment, libraries serve as the main sources of information for both learners and teachers for their work (Adeoye et al., 2011, pp. 65-77; White, 2012).

At-times-contending objectives-to protect owners' works on one hand, and to ensure adequate public access to works on the other-have also been with copyright law from inception (Tang, 2009). Copyright laws seek to mediate these contending interests through the mechanism of exceptions and limitations, which allow certain uses without requiring the consent of the copyright owner based on public interests and social policy goals (Samuelson, 2015). As Okediji (2006, p. ix) argues, exceptions and limitations "promote social goals such as education and basic scientific research" by enabling access to and use of protected works, as well as encouraging further creative activities. Thus exceptions and limitations typically allow use of protected work for purposes like "critical commentaries", news reporting, teaching and private study, preservation of materials by libraries and archives, and uses that lack economic significance (Samuelson, 2015, pp. 1-2). The existence of exceptions and limitations underscores the underlying concern that while protecting the economic rights of works' copyright owners, copyright laws should not engender barriers to publicinterest access (Alexander, 2010; Oguamanam, 2011). 


\section{Implications of digital technology}

The digital age has witnessed the permeation of digital technology into virtually every area of human endeavour, including education. Digital technology has various implications arising from its transformative effects, and dilemmatic consequences on data processing and use. Digital technology transforms the way knowledge-based products are produced, reproduced, disseminated and appropriated. Capacity and efficiency in the storage, manipulation and transmission of data makes it possible for the easy recording, storage and instantaneous transmission of data. Perfect copies of an existing work can be made and instantly distributed worldwide at minimal cost. A digital work can also be easily manipulated to create a new work. In general, in the absence of deliberate measures to prevent such activities, digital content can be easily accessed, shared, manipulated, and adapted to individual needs (Olojo et al., 2012, pp. 204-205).

These attributes should, thus, make TLMs in digital formats easily accessible within the meaning of "access to TLMs" as explained earlier. Teachers and students can easily obtain and examine new materials, adapt existing materials to their needs, and share materials in their possession. But this is where one of the diverse and conflicting consequences of digital technology manifests (CIPR, 2002; National Research Council, 2000). Digital technology enables works' copyright owners to have great control over access to and use of the content, through technology-assisted technological protection measures (TPMs) and encryption. As will be seen later, such control can easily affect access to, and use of, TLMs by teachers and learners, even for materials that they have legitimately acquired.

The transformations instituted by digital technology have had strong impacts on education in other ways, particularly in the inauguration of e-learning. E-learning represents a shift from traditional to ICT-based learning, and it makes quality education available at times of the learner's choice and at places suited to his or her requirements. This means that learners at different places can access information individually without geographical limitations (European Commission, 2013; Olojo et al., 2012, pp. 203-204; Naidu, 2006; Thakrar et al., 2009). This can be seen in the massive open online courses (MOOCs) emerging from many world-class universities, which are accessible to participants across the world who ordinarily would not be able to access or afford the real-time courses (Czerniewicz et al., 2015). Similarly, social media interactive forums have become active and effective platforms for instruction and learning on various subjects. ${ }^{6}$ Although these platforms rely significantly on open content, ${ }^{7}$ such as open educational resources (OERs), materials

6 e.g., WhatsApp, Google Hangout, Skype.

7 These are content available under an open licence such as the Creative Commons suite of licences. Within the Creative Commons group of licences, there are different possible gradations of openness to choose from, dependent on the rights-holder's choice of conditions in respect of reuse, sharing, revising, and adaption. Generally, wide access is a vital component of open-licence solutions. 
protected by copyright are also in use, and remain susceptible to access barriers fostered by copyright (EC, 2013; Thakrar et al.,, 2009). Similarly, improvements in internet connectivity and diffusion of affordable portable e-devices "to disseminate and display teaching and learning materials" in digital formats have increased the potential for greater "access to and quality of education by providing access to more educational content" to teachers and learners (Trucano, 2013).

E-learning is gaining ground in the Nigerian education ecosystem, as an answer to the country's education needs, by offering free, low-cost and flexible education programmes (Chanda et al., n.d.; Ige Akindele, 2014, p. 67; Umo, 2013, p. 10), and innovative educational technologies are also becoming diffused as complements to traditional learning resources. Open and distance learning (ODL) initiatives now exist both within and outside Nigerian tertiary institutions, taking quality education to many who would otherwise be left out. ${ }^{8}$ Initiatives like the National Open University of Nigeria (NOUN), distance-learning institutes (DLIs) in Nigerian universities, MOOCs affiliated with prestigious tertiary institutions abroad such as Coursera and the Harvard-affiliated edX platform, are a few examples. Indeed, access to TLMs not only serves these e-learning platforms but also remains necessary for traditional institutions of learning at all levels to achieve their objectives. For all these initiatives, copyright remains a potential threat to accessing TLMs, particularly in the digital environment.

At the heart of the problem are the creation of new rights and distortions of key concepts that have traditionally underpinned the nature and contours of copyright laws. For example, the act of digitisation is a new form of copyright-protected use, creating additional burdens on users because they require fresh copyright clearances unless the act of digitisation is for purposes covered by an exceptions or limitation. This is because digitisation, which refers to the conversion of existing works in non-digital forms into computer-compatible digital forms, is ordinarily construed as "copying" (Christie, 2008, pp. 2-3). Therefore, for example, processes such as scanning hard copies of documents, or digital photographing of works, are equivalent to making a copy of the document of work. Related to this is the "right of making available to the public", which, in the digital era, includes the exclusive right of copyright owners to control the making available of their works by digital means, on an on-demand basis, for public consumption (WIPO Copyright Treaty (WCT), 1996, Art. 8; WIPO Performances and Phonograms Treaty (WPPT), 1996, Arts. 10,14). This kind of "making available to the public" is, again, an offspring of digital technology outside the parameters of copyright law as originally contemplated (Ginsburg, 2004). The incorporation of digital rights into the copyright framework

8 ODL is defined as "[...] any scheme of education or training that seeks systematically to remove barriers to learning, whether they are concerned with age, time, place or space. With open learning, individuals take responsibility for what they learn, how they learn and where they learn" (Distance Education UK, 2003). 
can, thus, significantly affect cultural institutions like libraries and archives in their efforts to digitise their collections and make them publicly accessible (Rosati, 2013; Hudson \& Kenyon, 2007). Digital rights are also pertinent to e-learning, which relies on online communication as the default mode of engagement and can have access to its online TLMs undermined where the required consent from a copyright holder cannot be easily obtained.

Given the revolutionary effects of digital technology on data, it is not surprising that the traditional meaning of key concepts which limited the scope of copyright protection, and marked the boundaries between what is protected and what is exempted, have equally been distorted. Digitisation of data has blurred the lines between copying and reading or merely viewing a work. Each use of a work can now be deemed a new use entirely. Access, which was traditionally taken as a given for the user, has been transformed into an act of copying and performance (Cronqvist, 2010, p. 4; Litman, 2006). The natural dichotomy between "copying" and "access" allowed copyright law to only restrict the act of "copying" but not of "access" (or use) of a work, leaving a system of knowledge appropriation that was inherently quite open. Meanwhile, the notion of "public", with reference to certain rights like "publication", "distribution" and "communication to the public", has become distorted, with no clear distinction between public and private settings on the internet (National Research Council, 2000). Consequently, activities which hitherto constituted private acts by individuals, and on the basis of which they were exempted from copyright, now qualify as "publication" or "communication to the public" as via the borderless and openness-oriented public internet. These distortions have implications for individual learners and teachers, and inevitably compromise copyright's balancing mechanisms (National Research Council, 2000).

Digital technology has also enabled copyright owners to use TPMs and encryption technologies to further protect works. TPMs,implemented through technological and legal protocols, seek to address the weaknesses (from copyright owners' perspective) of copyright law by checkmating the ease of infringing use of digital content (Digital Millennium Copyright Act, 1998). They involve the use of technology to directly control access to, and use of, digital content, and the legal protection of these technologies against circumvention (WCT, Art. 11; WPPT, Art. 18). Such control is effected through licences and contracts that define the terms of use, with the terms sometimes exceeding internationally-agreed minimum protection standards and forcing users to have to deal with "triple locks" (EIFL, 2009a, p. 8; 2009b). This is made possible because contractual terms, often in the form of licences, take precedence over copyright law once a user has agreed to the terms. Such terms readjust the scope of the limitations and exceptions by controlling uses in ways not allowed under the law or by expanding the scope of protection in their definition of terms, e.g., giving a very narrow definition of the term "non-commercial" in setting out exceptions allowing for "non-commercial use". 
Digital technology has, thus, had significant impact on international and national copyright regimes, with grave implications for the original balance between owners' rights and access by the public. Accordingly, at the same time that steps have been taken to incorporate new uses and protections into the bouquet of rights reserved for owners of works, there is also growing concern for public access to published works, giving rise to new international instruments or proposed instruments with greater focus on exceptions and limitations. It is such concerns that led to adoption of the 2013 WIPO Marrakesh Treaty to Facilitate Access to Published Works for Persons who are Blind, Visually Impaired, or otherwise Print Disabled (MVT) (hereafter "Marrakesh Treaty"), and which have led to the ongoing efforts to conclude a treaty that caters for the needs of libraries and other cultural institutions in serving their users (Hackett, 2016).

\section{Nigerian Copyright Act and access to TLMs}

A close examination of the current Nigerian Copyright Act against the foregoing background reveals critical deficiencies. Works eligible for protection under the Act are: (a) literary works; (b) musical works; (c) artistic works; (d) films; (e) sound recordings; and (f) broadcasts. ${ }^{9}$ While these are undoubtedly within the normal scope of protected subject matter, the Act does not incorporate sufficient safeguards in the form of exceptions and limitations to ensure the necessary balance between incentivising copyright owners and enabling access to copyrighted works, including TLMs, in any of these forms. This is not out of tune with the fact that the Act was enacted in $1988,{ }^{10}$ and so precedes developments in copyright reform globally as precipitated by digital technology. Treaties such the aforementioned WIPO Internet Treaties, WCT and WPPT, are therefore not reflected in the Act. ${ }^{11}$ Even though driven more by a protectionist agenda than by a concern for access, these treaties nevertheless seek, among other things, to regularise the treatment of circumvention of TPMs, and do provide exceptions that to some extent seek to safeguard use of work for legitimate public-interest purposes.

At the outset, it can be called into question why the Act positions exceptions as a "schedule"—as the Second Schedule, linked to section 6(1) of the Act-outside the main provisions on owners' rights and thus potentially suggesting that the exceptions are secondary instead of core obligations for copyright owners. More substantively, the exceptions provided in the Second Schedule are inadequate for the digital era and for TLM access.

The Second Schedule stipulates actions which are exempted from the right of works' owners to control the use of the works, i.e., exceptions to copyright, and defences

9 Section 1(1).

10 It operates as amended in 1999 (and as codified in 2004) (Adewopo, 2012; Ola, 2015).

11 The 1999 amendment of the Act addressed mainly the issue of collective copyright management and administration. 
against charges of copyright infringement. The Second Schedule provides in paragraph (a) that copyright shall not apply to "the doing of any of the acts mentioned in the said section 6 by way of fair dealing for purposes of research, private use, criticism or review or the reporting of current events", subject to due attribution of the authorship of the work if used in public, except in case of the use being an incidental inclusion in a broadcast. The determination of what is "fair" is not stated in the Act, but Nigerian courts have generally been guided by the decisions of British courts on the UK's fair dealing provision (upon which the Nigerian model is based) to determine what is "fair" within the context of the Act. ${ }^{12}$ In the landmark 1972 case of Hubbard v Vosper ${ }^{13}$ on this issue, the Court held per Lord Denning as follows:

It is impossible to define what is fair dealing. It must be a question of degree. You must consider first the number and extent of the quotations and extracts. Are they altogether too many and too long to be fair? Then you must consider the use made of them. If they are used as a basis for comment, criticism or review, that may be a fair dealing. If they are used to convey the same information as the author, for a rival purpose, that may be unfair. Next, you must consider the proportions. To take long extracts and attach short comments may be unfair. But, short extracts and long comments may be fair. Other considerations may come to mind also. But, after all is said and done, it must be a matter of impression. As with fair comment in the law of libel, so with fair dealing in the law of copyright. The tribunal of fact must decide. (Hubbard v Vosper [1972] 2 QB 84)

This decision suggests that fair dealing is an issue that must be decided on a case-bycase basis at the discretion of a court of law.

In the context of access to TLMs, the potential impact of the Act's fair dealing exception is constrained by the fact that educational purposes are not included in the list of fair dealing "purposes", despite education's utilitarian, socioeconomic and socio-cultural value, its importance as a right for the Nigerian child, and its status as a cornerstone obligation of government to its citizens. Educational uses are only exempted from copyright in a number of narrowly-defined instances in the Second Schedule. These include the following:

- paragraph (f) provides an exception for inclusion of "not more than two excerpts" of a copyrighted work in a collection of literary or musical work designed for educational purposes and accompanied by an acknowledgement of the authorship;

- paragraph (g) provides an exception for the broadcast of a work "as an educational broadcast";

- paragraph (h) provides an exception for "any use of a work in an approved

12 See sections 29 and 30 of the UK Copyright, Designs and Patents Act 1988: https://www.legislation.gov.uk/ukpga/1988/48/introduction

13 Hubbard v Vospar [1972] 2 QB 84. 
educational institution for the educational purposes of that institution", but any reproduction made for such purposes must be destroyed as prescribed or within 12 months in the absence of any such prescription; and

- paragraph (k) provides an exception for use of a work by prescribed "public libraries, non-commercial documentation centres, and scientific or other institutions as may be prescribed, where use is in the public interest" and is non-revenue-generating.

A significant weakness in the Act's provisions on exceptions is the absence of provisions on TPMs, which have the potential to truncate even the most inclusive and open-ended forms of exceptions and limitations. This gap may be seen as providing an open field for unrestrained circumvention of TPMs, thus being ostensibly proaccess. But it also enables works' copyright owners to unduly restrict access to their works in the absence of the necessary exceptions which take cognizance of new uses. Other gaps in the law relate to new concerns, in the digital era, around: libraries and similar cultural institutions serving the needs of the public; access for print-disabled persons; and non-recognition of digital rights.

\section{The draft Bill and provisions relevant to TLMs}

There is no gainsaying the fact that the draft Copyright Bill inaugurates an important template for aligning Nigeria's copyright system with the digital age. It also represents an important milestone in copyright reform in Nigeria, given the inclusiveness of the process leading to the draft Bill — with inputs synthesised from a series of deliberations with stakeholders, focus groups, and public comments (Standeford, 2015). The draft Bill is therefore a conscious effort to remodel the Nigerian copyright law for the digital age and for the benefit of both the copyright industries and the user public. In a way that brings digital copies under the copyright paradigm, the draft Bill defines "copy" in section 85(1) as "a reproduction in any form including a digital copy". This differs from the definition of "copy" in section 51 of the Act which does not make reference to "digital copies".

The draft Bill delineates the scope of protectable works subject to exceptions that apply generally, and others that are specific to print-disabled persons and cultural institutions (sects. 21 and 22). Again this is a deviation from the Act, which recognises special exceptions for only sound recordings, in its Third Schedule. Like the Act, the draft Bill also provides both civil and criminal penalties for the infringement of copyright (Parts IV and V, respectively, of the draft Bill). ${ }^{14} \mathrm{~A}$ proactive effort to ensure a balanced law is seen in sections 27-31 of the draft Bill, which allow resort to compulsory licences for public interest goals. With 88 sections in all, the draft Bill certainly seeks to move Nigerian copyright law into the digital era. I now turn to examination of the provisions of the draft Bill that are relevant to the focus of this article: access to TLMs.

14 The relevant sections in the Act are 15-30. 
The draft Bill highlights, among its main objectives, the need to: align the copyright system with international treaties; position the creative industries for greater competiveness in the "digital and knowledge-based economy"; and "effectively protect the rights of authors to ensure just rewards and recognition for their intellectual efforts" while also "providing appropriate limitations and exceptions to guarantee access to creative works", encouraging "cultural exchange", and advancing "public welfare" (draft Bill, Policy Considerations, p. 3). These preambulatory policy guidelines underscore balance as a major concern, with emphasis on access. These policy guidelines therefore distinctly mark the balanced philosophy, not specified under the current law, which should underpin the future of copyright protection in Nigeria. Structurally, too, the draft Bill significantly deviates from the Act by incorporating exceptions as part of the main provisions and not as an appendage in a schedule.

In line with its stated objectives, the draft Bill assigns to owners of copyrightable works the exclusive right to control a number of uses of their works (sect. 8-12). These include the right to reproduce, publish, or adapt the work, or to communicate the work to the public. It also protects the rights to publish and produce translations of literary and musical works specifically. Part II provides exceptions for certain uses which would not require the authority of the work owner once the necessary conditions are established. The exceptions provided are of two categories: those, in section 20, applicable generally (except where otherwise provided in the draft Bill), and those applicable to specific users (sect. 21).

\section{General exceptions}

Under general exceptions, section 20(1)(a) imports (and expands) the fair dealing exception in the Act by exempting activities which qualify as fair dealing "for purposes of research, teaching, education, [emphasis added] private use, criticism, review or the reporting of current events", subject to attribution of authorship where the use is public. This differs from the more restricted scope of the fair dealing provision in the Act, which does not cover teaching and education. The question of whether a certain use constitutes fair dealing would, in terms of the draft Bill, depend on certain mandatory conditions contained in the proviso of sub-section 20(1)(a), which provides that:

$[\ldots]$ in determining whether the use made of a work in any particular case is fair dealing, the factors to be considered shall include-

(i) the purpose and character of the use, including whether such use is of a commercial nature or is for non-profit educational purposes;

(ii) the nature of the work;

(iii) the amount and substantiality of the portion used in relation to the work as a whole;

(iv) the effect of the use upon the potential market for or value of the work; and 
(v) if the use does not conflict with a normal exploitation of the work and does not unreasonably prejudice the legitimate interests of the owner of copyright. (draft Bill, sect. 20(1)(a))

As is discussed below, this draft section 20(1)(a) simultaneously, and problematically, both widens and narrows the scope of the fair dealing exemption.

More clearly encouraging for access to TLMs, the draft Bill's section 20(1) general exceptions also include, in addition to the fair dealing exception, exceptions for the benefit of libraries (sect. 20(1)(i), (n)), educational use (sect. 20(1)(f)), persons with disability (sect. 20(1)(q), and for purposes of (private) research and study sect. 20(1)(o), (t)). The general exceptions in the draft Bill's section 20(1) incorporate (and in some cases modify) some of the exceptions contained in the existing Act's aforementioned Second Schedule. For example, the draft Bill's section 20(1)(n), which allows the making of not more than three copies of a work by public libraries, and section 20(1)(o), which allows public libraries and other public institutions to reproduce unpublished literary or musical works in their possession for the purpose of research or private study, both have replicas in the existing Act.

\section{Specific exceptions}

The specific exceptions provided for in the draft Bill include "[s]pecial provisions for archives, libraries, museums and galleries" (sect. 21), and "[s]pecial exceptions for Blind, Visually Impaired, or Otherwise Print Disabled Persons" (sect. 22). There are also "[s]pecial exceptions in respect of a sound recording of a musical work" (sect. 23).

The special exceptions provided in the draft Bill's section 21 and 22 to (1) archives, libraries, museums and galleries, and to (2) visually impaired persons, address obligations arising from global concern for library-friendly copyright laws and recent international treaties. Both these sets of exceptions have far-reaching implications for access to TLMs by teachers and students alike in Nigeria.

Section 21's exceptions can assist Nigerian libraries and similar cultural institutions to alleviate the negative consequences of digital technology on their activities, and at the same time to harness the potential of digital technology to enhance their services. Section 21(1) permits libraries to distribute and share materials among themselves for non-commercial purposes, as part of their normal function of preserving and lending books to the public. Libraries are therefore accorded greater freedom to use digital materials and to integrate their services through consortiums, thus making educational materials more accessible. ${ }^{15}$ Sections $21(2)$ (a) and (c) permit libraries to make copies of their existing works in other formats, including digital formats. Section 21(2)(a) permits archives, libraries, museums and galleries to "may make copies of

15 As is the case in South Africa, where such consortiums exist among universities. 
works in their collection for the purpose of back-up and preservation". Section 21(2) (c) permits them to also "make copies of works that are or should be available in their collections in their chosen format, if they cannot reasonably be acquired in such format through general trade or from the publisher". Libraries can also make copies to complete an incomplete collection, where the work cannot reasonably be acquired through general trade or directly from the publisher (sect. 21(2)(b)); they can make whole copies of their collections where the required permission cannot be obtained and the work is not available by general trade or from the publisher (sect.21(2)(d)); and the copies they make can be accessed and used on their premises or lent to their users (sect. 21(2)(e)).

The draft Bill's section 22 "special exceptions" for the print-disabled seek to bring Nigerian copyright law in alignment with the Marrakesh Treaty. Section 22(1) allows anyone having lawful access to a work, or copy of a work, to make it available in formats that print-disabled persons can conveniently access and/or utilise, without the need for the copyright owner's permission. This is, however, legal only if the production of the format for print-disabled is for non-commercial purposes and the copy is properly attributed. Section 22(3) permits importation of the desired format for non-profit uses, which constitutes an exception to provisions in the draft Bill prohibiting importation of copyrighted works. ${ }^{16}$

\section{Provisions on circumvention of technological protection measures (TPMs) and rights management information}

The draft Bill's sections 44 and 45 provide an entirely new set of provisions aimed at adopting international standards, as required by the aforementioned WIPO Internet Treaties, in respect of circumvention of TPMs used to protect works, and in respect of electronic rights management information. ${ }^{17}$ (Nigeria deposited its ratification instruments for these treaties with WIPO on 4 October 2017, and is now in the process, through the draft Bill, of domesticating its obligations.) The TPM provisions outlaw circumvention of TPMs and production and dissemination of devices used for circumventing TPMs. ${ }^{18}$

In all instances, exceptions are provided to ensure that legitimate acts requiring circumvention of TPMs are not affected. For instance, circumvention of devices required by a person qualified under the draft Bill to execute a permitted act is not prohibited (sect. 44(9)). This accentuates the distinction between access and use in connection with the circumvention of TPMs to avoid the unintended consequence of criminalising legitimate access (National Research Council, 2000). Section 44(8) provides that the protection of TPMs "shall not affect the exceptions provided in [the] Act as it relates to the work in respect of which the technological protection

16 Sections 32(1)(b), 38(1)(b), 79(1) and 79(6).

17 Sections 44 and 45.

18 Sections 44(1) and 44(2). 
measure is applied". It can be assumed that circumvention by the visually impaired, in order to access content in accordance with section 22(1), would constitute use that satisfies legitimate access and so is therefore permissible. However, even with this section 44(8) recognition that TPMs should not affect uses permitted via exceptions, the TPM anti-circumvention provisions still raise fears in respect of limitation of users rights (with relevance to TLMs) — due to the additional capacity TPMs provide for copyright owners to control even normal uses of their work, such as format- and time-shifting (see EIFL, 2009a, p. 8)). Also of concern is the ability of copyright owners to impose contractual terms or licensing requirements that undermine lawful TPM circumvention that is provided for by exceptions. (See "Weaknesses and gaps in the draft Bill" section below for more on this matter.)

\section{The right of communication to the public}

The draft Bill, in section 85, redefines the right of communication to the public to include the right of making available to the public. This no doubt provides additional means for copyright owners to control the dissemination of their digital works. But again, consideration is given to access to TLMs by providing exceptions to aid education and learning. The draft Bill protects the right of communication to the public in respect of literary and musical works (sect. 8(1)(h)), films (sect. 10(d)), and sound recordings (sects. 11(d) and 14(7)). Section 85(1) makes it clear that communication to the public includes "live performance or delivery, any mode of visual or acoustic presentation, making available the work or copies thereof to the public, including by digital transmission over computer networks, but does not include a broadcast or re-broadcast; [...]". However, section $20(1)(\mathrm{t})$ allows communication or making available copyrighted material "for the purpose of research or private study, to individual members of the public by dedicated terminals on the premises of publicly accessible libraries, educational establishments, museums and archives, of works and other subject matter not subject to purchase or licensing terms which are contained in their collections".

\section{Redefinitions relevant to copying, publication}

The draft Bill redefines certain concepts to specify their meaning in the digital environment. Section 85(1) defines "copy" to include making digital copies of a copyrighted work. But read in conjunction with section 20(1)(q), this does not include:

temporary acts of reproduction which are transient or incidental and an [...] essential part of a technological process and whose sole purpose is to enable a transmission in a network between third parties by an intermediary; or for other lawful use, where such use has no independent economic significance. (draft Bill, sect. 20(1)(q)) 
To accommodate the meaning of publication in the digital environment, where an individual with access to internet becomes a potential publisher, the draft Bill, in section 85(2)(a), deems a work as published "if copies of it have been made available in a manner sufficient to render the work accessible to the public". This means that a work is published once it is uploaded on the internet. (Such provisions can, on the whole, have negative implications for access to TLMs in the absence of adequate exceptions. We saw above the draft Bill's provision of exceptions for libraries desirous of making digital copies of existing collections for non-profit uses.)

\section{Compulsory licensing}

The draft Bill's prioritisation of access as an overriding public interest related objective is highlighted in its provisions for compulsory licences in sections 27,28 and 31-which are much more far-reaching than the compulsory licence provisions in the current Act. The draft Bill's provisions on compulsory licences are no doubt designed to make learning materials more accessible in local languages, and to address the scarcity of publications in Nigeria-particularly textbooks and other science and technology-related publications. Section 27(1) provides as follows:

Any qualified person may apply to the Commission [NCC] for a licence to produce and publish a translation of a literary work which has been published in printed or analogous forms of reproduction for the purposes of teaching, scholarship or research. (draft Bill, sect. 27(1))

In effect, section 27 allows the NCC to grant a non-exclusive licence to qualified persons to produce and publish translations of TLMs in all languages for use within Nigeria. For this purpose, it does not matter whether the translation is a commercial or non-profit project. Such works can also be officially used in one of two ways outside Nigeria if they are "in any language other than English". In terms of section 27(5), copies of translated works in any language other than English can be "sent to citizens of Nigeria residing outside Nigeria or to any association of such citizens outside Nigeria; or used for purposes of teaching, scholarship or research and not for any commercial purpose". In all cases, in terms of section $27(7)(a)$, an application for a licence will not be approved unless:

the Commission is satisfied that no translation of the work into the language in question has been published in printed or analogous forms of reproduction, by or with the authorization of the owner of the right of translation, or that all previous editions in that language are out of print; [...]. (draft Bill, sect. 27(7)(a))

Similarly, section 28 of the draft Bill allows licences to be granted by the NCC to qualified persons to reproduce and publish affordable copies of literary or artistic works in printed format which are not available in the market for up to six months, 
or where they are to be used in connection with systematic instructional activities. This provision is undoubtedly an important measure to stem scarcity and overpricing of TLMs, especially textbooks. In addition, section 31 of the draft Bill, entitled [c] ompulsory licenses for public interest" empowers the NCC to authorise the use of TLMs in the overall interest of the public as follows:

(1) Notwithstanding any other section of this Act, the Commission may authorize the use of a work by any person for the following purposes-

(a) to rectify abuse of dominant market position;

(b) to remedy abuse of rights;

(c) to promote public interest. (draft Bill, sect. 31(1))

An important qualification to this privilege is section 31's subsection 2, which provides:

(2) In authorizing the use of a work under subsection 1 of this section, the Commission shall take into consideration the following-

(a) that prior to such use, the proposed user has made efforts to obtain authorization from the owner of copyright on reasonable commercial terms and conditions and that such efforts have not been successful within a reasonable period of time:

Provided that the Commission may waive this condition in the case of a national emergency or other circumstances of extreme urgency or in cases of public non-commercial use; and

(b) the owner of copyright is accordingly notified; [...]. (draft Bill, sect. 31(2))

The expression "on reasonable commercial terms and conditions" represents a marked difference with sections 27 and 28, where the reasonableness of the terms upon which the owner of the work is willing to permit use is not said to be a consideration in the question of whether grant of a compulsory licence is warranted/defensible. Moreover, in section 31(2) there is also provision for the "efforts to obtain authorisation" requirement to be waived in three cases: "national emergency", "other circumstances of extreme urgency" and "cases of public non-commercial uses". These cases could be interpreted to accommodate any number of scenarios, but in the context of TLMs, it implies that for the purpose of public education, compulsory licences could be granted for the printing of scarce materials relevant to education in critical areas like medicine, science and technology.

The draft Bill does not define "public interest", thereby leaving it open and subjective. It could be argued that the omnibus nature of the section is intended to cover as many circumstances as possible. A typical public interest rationale would be to remedy a situation where copyright producers do not see profit in certain kinds of works, e.g., “works in'neglected languages' spoken predominantly by poor people" (Shaver, 2014, 
p. 124), or publications for diseases of the poor leading to scarcity of such materials for teaching and learning the subject.

The key broadening of the compulsory licence provisions in the draft Bill is via section 31 on "[c]ompulsory licenses for public interest", which does not have an equivalent in the provisions of the Act (in the Act's Fourth Schedule).

\section{Weaknesses and gaps in the draft Bill}

There is no gainsaying the fact that the draft Bill upgrades the protection of works in Nigeria in the digital age, with thoughts also given to facilitating access to TLMs. Overall, the exceptions enhance the prospects of accessing TLMs in Nigeria by allowing uses of copyrightable materials for private study and research; and provisions to help libraries and similar cultural institutions serve their users better. The special exceptions provided under sections 21 and 22 go a long way in addressing obligations arising from new treaties and the concern for $\mathrm{A} 2 \mathrm{~K}$ in the digital age for all. And the strong public interest orientation of the compulsory licensing provisions is potentially very positive for TLM access in the country. However there are also potential weaknesses and gaps, which I now discuss.

\section{The fair dealing provision}

As stated above, the draft Bill's section 20(1)(a) on fair dealing potentially both widens and narrows the scope of the fair dealing exemption. The addition of "education and teaching" to the fair dealing exemptions widens the scope of the exception by allowing for the use of copyrighted works for educational purposes without requiring the consent of works' owners, thereby potentially facilitating access to TLMs. ${ }^{19} \mathrm{But}$ at the same time, the section stipulates new conditions for application of fair dealingconditions which potentially narrow the exception by mirroring, in section 20(1) (a)(v), elements of the "three-step test" found in key international instruments (Berne Convention, Art. 9(2); TRIPS Agreement, Art. 13; WCT, Art. 10; WPPT Art. 16(2)). ${ }^{20}$ Given the background of the three-step test as the outcome of strong lobbying by copyright industries, its primary objective is to expand the protection granted to copyright owners by strengthening their rights, and it does so in a vague manner that leaves ample room for access-unfriendly interpretation.

The three-step test is composed of mandatory conditions that seek to ensure that work owners are not affected by exceptions in a way that deprives them of the "normal exploitation" of their rights (Christie \&Wright, 2014, p. 26). The test, which has its origins in the 1967 revision of the Berne Convention, states that exceptions to copyright protection shall: (1) only affect "certain special cases", (2) that do "not conflict with a normal exploitation of the work", and (3) that do "not unreasonably prejudice the legitimate interests of the author" (Berne Convention, Art. 9(2)). All

19 Section 20(1) (a) (f).

20 See EFF (n.d.) on three-step test. 
three conditions in the test must be reasonably satisfied before a particular use can be considered as exempted. The draft Bill's section 20(1)(a)(v), in mirroring elements of the three-step-test, is thus potentially access-unfriendly (Geiger, 2007; Geiger et al., 2014). Jaszi, Carroll, and Flynn (2016) have recommended the removal of 20(1)(a) (v), and I too make this recommendation.

I am also in agreement with the recommendation by Jaszi et al. (2016) that, in order to give the draft Bill's sect.20(1)(a) fair dealing provision more potential openness of interpretation by the Nigerian courts-with such openness of judicial interpretation being one of the strengths of the US "fair use" doctrine- that the draft Bill's sect. 20(1)(a) introductory language be changed. ${ }^{21}$ Section 20(1)(a) currently states:

the doing of any of the acts mentioned in the said sections by way of fair dealing for purposes of [emphasis added] research, teaching, education, private use, criticism, review or the reporting of current events, subject to the condition that, if the use is public, where practicable, it shall be accompanied by an acknowledgment of the title of the work and its authorship except where the work is incidentally included in a broadcast; [...]. (draft Bill, sect. 20(1)(a))

I concur with the Jaszi et al. (2016) recommendation that, in order to broaden the fair dealing exception, the word "of", as italicised above in the quote from 20(1)(a), be replaced with the words "such as" (Jaszi et al., 2016, p. 9).

\section{TPM anti-circumvention provisions}

The TPM anti-circumvention provisions, while generally favourable to TLMs access and use, are also a cause for some concern, as alluded to above. It is indisputable that the inclusion of protection of TPMs adds layers of protection not originally contemplated by the Act, thus strengthening copyright protection for copyright holders. Protecting TPMs can have unfavourable consequences in respect of access, not the least access to TLMs. While there is a need to reinforce protection for works in the light of rampant and random infringement of digital content in the country, it is equally important that the provisions do not unduly restrict access beyond the boundaries intended by the law. This is what the provisions on TPMs seek to ensure by distinguishing between lawful and unlawful uses in prohibiting circumvention, with section 44(8) making clear that protection of TPMs against circumvention does not affect the exceptions stipulated in the Act.

However, the objective of ensuring that protection of TPMs does not undermine exceptions would benefit from an additional measure in the draft Bill: a provision safeguarding lawful uses against overreaching contractual terms or licensing requirements. Such a safeguard could take the form of an omnibus "catch-all" clause

21 See De Zwart (2006) for comparison between US fair use model and Australian fair dealing provisions. 
covering exceptions and limitations generally, as suggested by Jaszi et al. (2016). Jaszi et al. (2016) recommend the insertion of an omnibus clause that "[c]ontractual terms which purport to restrict or prevent the doing of the acts permitted by limitations and exceptions under this Act are unenforceable". Such a clause, which finds precedents in UK copyright law ${ }^{22}$ and the South African Copyright Amendment Bill 2015, ${ }^{23}$ would invalidate contractual terms seeking to restrict or prevent the doing of acts permitted by the embedded limitations and exceptions (Jaszi et al., 2016, p. 13). The absence of such a provision in the draft Bill can be seen as a clear gap that needs filling if TLM access is to be maximised.

\section{Communication to the public}

The draft Bill's section 20(1)(t), which exempts from copyright protection communication to the public for the purposes of research and private study, ensures that TLMs can be disseminated among teachers and learners in public institutions through secured terminals. But the fact that the exception does not apply to content which is subject to purchase or licensing terms means that copyright authorisations are still necessary for such cases. This makes the exemption somewhat superficial, as the only items not requiring copyright authorisations are likely to be open materials for which access is already not restricted, such as open educational resources (OERs), open access publications, and publications carrying Creative Common licences. Again, contractual terms will potentially override the exception, making this provision a potential weakness in the draft Bill in respect of bolstering TLM access.

\section{Conclusion}

Several provisions in Nigeria's draft Copyright Bill have the potential to improve access to TLMs, in turn serving the education needs of Nigerians and the education polices of the government. Provisions in the draft Bill would improve on the extant Act by broadening the scope of exceptions for education and research purposes, aligning them with the realities of the digital age, for both individuals and institutions. The draft Bill also seeks to introduce provisions to address the needs of the print-disabled, in line with new international standards. To address the problems of scarcity and high prices of learning materials, the draft Bill provides for more robust provisions in support of use of compulsory licences. In sum, the draft Bill's recognition of new rights, its realignment of existing rights, and its expansion of exceptions to cover more education-related needs, would, if passed into law, significantly strengthen the user-access side of copyright's balancing objective. This would enhance the potential of access to, and use of, TLMs under the law.

At the same time, the Bill has weaknesses and gaps in respect of its efforts to ensure adequate access to TLMs in the digital era in Nigeria. Its fair dealing exception

22 See UK Government (2014); and UK Copyright, Designs and Patents Act 1988: https://www.legislation.gov.uk/ukpga/1988/48/introduction

23 See https://www.gov.za/sites/default/files/39028 gon646c.pdf 
requires refinement so as to not lead to overly narrow judicial interpretations of the exception; its TPM anti-circumvention provisions would benefit from additional measures safeguarding lawful uses against overreaching contractual terms or licensing requirements; and the draft Bill's section 20(1)(t) on "[c]ommunication to the public" requires reconsideration to see if it can be broadened.

As the process of amending the Nigerian copyright law unfolds, it is important that the salient terms of the current draft Bill be maintained, accompanied by a conscious effort to address the weaknesses and gaps identified above, in order to create a legitimate framework that enables and fosters access to TLMs for all in Nigeria in the digital age.

\section{References}

\section{Legal instruments}

Agreement on Trade-Related Aspects of Intellectual Property Rights (TRIPS Agreement), 1994. World Trade Organisation (WTO). Retrieved from https://www.wto.org/ english/docs_e/legal_e/27-trips.pdf

Berne Convention for the Protection of Literary and Artistic Works, 1982. World Intellectual Property Organisation (WIPO). Retrieved from https://www.wipo.int/treaties/en/ ip/berne/

Child's Rights Act, 2003: An Act to Provide and Protect the Right of the Nigerian Child and other related matters. Act No. 26 of 2003. Cap C50 LFN 2004. Federal Republic of Nigeria. Retrieved from https://www.refworld.org/docid/5568201f4.html

Compulsory, Free Universal Basic Education Act, 2004. Federal Republic of Nigeria. Retrieved from https://www.lawyard.ng/wp-content/uploads/2016/01/COMPULSORYFREE-UNIVERSAL-BASIC-EDUCATION-ACT2004.pdf

Constitution of the Federal Republic of Nigeria (Promulgation Act), 2004. Cap C23 LFN 2004. Retrieved from http://www.lawnigeria.com/CONSTITUTIONHUB/index. $\underline{\mathrm{html}}$

Convention on the Rights of the Child, 1989. United Nations. Retrieved from https://treaties. un.org/doc/Treaties/1990/09/19900902\%2003-14\%20AM/Ch IV 11p.pdf

Copyright, Designs and Patents Act 1988. United Kingdom. Retrieved from https://www. legislation.gov.uk/ukpga/1988/48/introduction

Digital Millennium Copyright Act (DMCA), 1998. United States of America. Retrieved from https://www.gpo.gov/fdsys/pkg/PLAW-105publ304/pdf/PLAW-105publ304.pdf

Draft Copyright Bill 2015, Nigerian Copyright Commission. Retrieved from http:// graduatedresponse.org/new/wp-content/uploads/2016/02/DRAFT_ COPYRIGHT BILL NOVEMBER- 2015.pdf

Marrakesh Treaty to Facilitate Access to Published Works for Persons who are Blind, Visually Impaired, or otherwise Print Disabled (MVT), 2013. World Intellectual Property Organisation (WIPO). Retrieved from http://www.wipo.int/wipolex/en/treaties/ text.jsp?file id=301016 
Nigerian Copyright Act, 1988. Cap C28 LFN, as codified 2004. Federal Republic of Nigeria. Retrieved from http://www.copyright.gov.ng/index.php/legislationregulations/227-the-nigerian-copyright-act-cap-c28

Statute of Anne, 1710. Retrieved from http://www.copyrighthistory.com/anne.html

Universal Declaration of Human Rights, 1948. United Nations. Retrieved from http://www. un.org/en/universal-declaration-human-rights/

U.S. Copyright Act, 17 U.S.C. $\S \S 101$ et seq. United States of America. Retrieved from https://www.wipo.int/wipolex/en/text.jsp?file id=130040

WIPO Copyright Treaty (WCT), 1996. World Intellectual Property Organisation (WIPO). Retrieved from https://www.wipo.int/treaties/en/ip/wct/

WIPO Performance and Phonograms Treaty (WPPT), 1996. World Intellectual Property Organisation (WIPO). Retrieved from https:/www.wipo.int/treaties/en/ip/wppt/

\section{Secondary sources}

Adeoye, M. O., \& Popoola, S. O. (2011).Teaching effectiveness, availability, accessibility, and use of library and information resources among teaching staff of schools of nursing in Osun and Oyo State, Nigeria. Library Philosophy and Practice, 525. Retrieved from http://digitalcommons.unl.edu/libphilprac/525/

Adesomoju, A. (2017, March 1). Court declares free, compulsory basic education an enforceable right. Punch. Retrieved from https://punchng.com/court-declares-freecompulsory-basic-education-an-enforceable-right

Adewopo, A. (2012). According to intellectual property: A pro-development vision of the law and the Nigerian intellectual property law and policy reform in the knowledge era. $5^{\text {th }}$ Inaugural Lecture, Nigerian Institute of Advanced Legal Studies (NIALS), Lagos.

Alexander, I. (2010). Copyright law and the public interest in the nineteenth century. Oxford: Hart Publishing. https://doi.org/10.5040/9781472565013

Amuda, Y. J. (2011). Child education in Nigeria: Hindrances and legal solutions. ProcediaSocial and Behavioral Sciences, 15, 3027-3031. https://doi.org/10.1016/j.sbspro.2011.04.237

Armstrong, C., De Beer, J., Kawooya, D., Prabhala, A., \& Schonwetter, T (Eds.). (2010). Access to knowledge in Africa: The role of copyright. Cape Town: UCT Press.

Aronsson-Storrier, A. (2016) Copyright exceptions and contract in the UK: The impact of recent amendments. Queen Mary Journal of Intellectual Property, 6(1), 111-123. https://doi.org/10.4337/qmjip.2016.01.06

Brende, B. (2015). Why education is key to development. World Economic Forum. Retrieved from https://www.weforum.org/agenda/2015/07/why-education-is-the-key-todevelopment/

Chanda, D. H., Phiri, S. N. A., \& Nkosha, D. C. (n.d.). Teaching and learning materials analysis and development in basic education. UNESCO Basic Education Capacity Building Project: Training Kits for Local NGOs: Theme 3. Retrieved from http://unesdoc. unesco.org/images/0013/001320/132019eo.pdf 
Christie, A. F. (2007). Cultural institutions, digitisation and copyright reform. U of Melbourne Legal Studies Research Paper No. 303. Retrieved from https://ssrn.com/ abstract $=1081733$

Christie, A. F., \& Wright, R. (2014). A comparative analysis of the three-step tests in international treaties. ICC - International Review of Intellectual Property and Competition Law, 45(4), 409-433. https://doi.org/10.1007/s40319-014-0202-2

Clifford, I. B., \& Oghenenyerhovwome, O. F. (2014). Violation of copyright law through photocopying in tertiary institution: Case study of Delta State University Abraka. Journal of Educational Policy and Entrepreneurial Research, 1(2), 301-310.

Commission on Intellectual Property Rights (CIPR). (2002). Integrating intellectual property rights and development policy. Report of the Commission on Intellectual Property Rights. London: UK Government. Retrieved from http://www.iprcommission.org/ papers/pdfs/final_report/CIPRfullfinal.pdf

Cronqvist, J. (2010). The future of copyright: Digitisation and fair use in the digital millennium. Master's thesis, Faculty of Law, Lund University, Sweden. Retrieved from http://lup.lub.lu.se/luur/download?func=downloadFile\&recordOId=1698259\&fileOId $=1698263$

Czerniewicz, L., Deacon, A., Fife, M., Small, J., \& Walji, S. (2015). CILT position paper: MOOCs. Centre of Innovation in Learning and Teaching (CILT), University of Cape Town. http://hdl.handle.net/11427/14041

De Zwart, M. (2006). Fair use? Fair dealing? Copyright Reporter, 24(1\&2), 20-37.

Distance Education UK. (2003). Distance vs. open learning. Retrieved from http://www. distance-learning.co.uk/whatis/dlvol.htm

Electronic Frontier Foundation (EFF). (n.d.) The three step-test. Retrieved from https:// www.eff.org/files/filenode/three-step test_fnl.pdf

Electronic Information for Libraries (EIFL).(2016). EIFL Draft Law on Copyright including Model Exceptions and Limitations for Libraries and their Users Based on WIPO Draft Law on Copyright and related Eights (Version 2005). Recommendations by EIFL 2016. Work in Progress. Retrieved from http://www.eifl.net/system/files/ resources/201607/eifl draft law 2016 online.pdf

EIFL. (2009a). Handbook on copyright and related issues for libraries. Retrieved from http:// www.eifl.net/resources/eifl-handbook-copyright-and-related-issues-librariesenglish

EIFL. (2009b). Statement of principles on copyright exceptions and limitations for libraries.

European Commission (EC).(2013). Analysis and mapping of innovative teaching and learning for all through new technologies and open educational resources in Europe. Commission Staff Working Document.

Federal Ministry of Education. (2015). Education for all, a collective responsibility. Nigeria EFA Review Report 2000-2014. Retrieved from http://unesdoc.unesco.org/ images/0023/002310/231081e.pdf

Federal Republic of Nigeria. (2013). National Policy on Education (6th ed.) Lagos: Nigerian Educational Research and Development Council (NERDC). 
Geiger, C. (2007). From Berne to national law, via the Copyright Directive: The dangerous mutations of the three-step test.European Intellectual Property Review (EIPR), 29(12), 486-491.

Geiger, C., Gervais, D. J., \& Senftleben, M. (2014). The three-step test revisited: How to use the test's flexibility in national copyright law. American University International Law Review,29(3), 581-626. https://doi.org/10.2139/ssrn.2356619

Ginsburg, J. (2004). The (new?) right of making available to the public. Columbia Public Law \& Legal Theory Working Papers, Paper 0478. Retrieved from http://1sr.nellco.org/ columbia pllt $/ 0478$

Hackett, T. (2016). Core library exceptions and checklist: Does your copyright law support library activities and services? Electronic Information for Libraries (EIFL). Retrieved from http://www.eifl.net/system/files/resources/201607/core library checklist online. pdf

Hongladarom, S. (2007). Information divide, information and global justice. International Review of Information Ethics, 7, 1-5.

Hargreaves, I. (2011). Digital opportunity: A review of intellectual property and growth. Independent report for the UK Government. London. Retrieved from https:// www.gov.uk/government/publications/digital-opportunity-review-of-intellectualproperty-and-growth

Hudson, E., \& Kenyon, A. T. (2007). Digital access: The impact of copyright on digitisation practices in Australian museums, galleries, libraries and archives. U of Melbourne Legal Studies Research Paper No. 300. Retrieved from https://ssrn.com/abstract=1065622

Hughes, J. (1988). The philosophy of intellectual property. Georgetown Law Journal, 77, 287366.

Ige Akindele, M. (2014). Challenges facing the achievement of Education for All (EFA) and education related Millennium Development Goals (MDG) in Nigeria. Journal of Poverty, Investment and Development, 3, 65-72. Retrieved from https://www.iiste. org/Journals/index.php/JPID/article/view/9282

International Organisation for Migration (IOM). (2014). Needs assessment in the Nigerian education sector. Abuja. Retrieved from http://publications.iom.int/system/files/pdf/ needs_assessment_nigerianeducsector.pdf

Jaszi, P., Carroll, M., \& Flynn, S. (2016). Comments of U.S. copyright scholars on Draft Copyright Bill 2015: Nigerian Copyright Commission. Retrieved from http://www. pijip.org/wp-content/uploads/2016/01/PIJIP-NCC-comment.pdf

Jonker, J. D. (2009). Access to learning materials in South Africa: The convergence of developmental and rights-based arguments for access to knowledge. Retrieved from https://ssrn.com/ abstract $=1455943$

Kapczynski, A. (2010). Access to knowledge: A conceptual genealogy. In G. Krikorian, \& A. Kapczynski (Eds.) (2010), Access to knowledge in the age of intellectual property (pp. 17-56). New York: Zone Books.

Kretschmer, M., Derclaye, E., Favale, M., \& Watt, R. (2010). The relationship between copyright and contract law. Research commissioned by Strategic Advisory Board for Intellectual Property Policy (SABIP). London. Retrieved from http://eprints. bournemouth.ac.uk/16091/1/_contractlaw-report.pdf 
Krikorian, G., \& Kapczynski, A. (Eds.) (2010). Access to knowledge in the age of intellectual property. New York: Zone Books.

Lewinski, S. V. (2008). International copyright law and policy. Oxford: Oxford University Press. Litman, J. (2006). Digital copyright. New York: Prometheus Books.

Moja, T. (2000). Nigeria education sector analysis: An analytical synthesis of performance and main issues. For the World Bank. Retrieved from http://siteresources.worldbank. org/NIGERIAEXTN/Resources/ed_sec_analysis.pdf

Naidu, S. (2006). E-learning: A guidebook of principles, procedures and practices (2nd revised ed.). New Delhi: Commonwealth Educational Media Center for Asia (CEMCA).

National Planning Commission (NPC). (2009). Nigeria vision 20: 2020: Economic transformation blueprint. x Retrieved from http://www.nationalplanning.gov.ng/ images/docs/NationalPlans/nigeria-vision-20-20-20.pdf

National Research Council. (2000). The digital dilemma: Intellectual property in the information age. Washington, DC: National Academy Press.

https://doi.org/10.17226/9601

Nigerian Copyright Commission (NCC). (2018, June 29). Federal Executive Council approves Draft Copyright Bill 2017. Retrieved from http://www.copyright.gov. ng/index.php/news-events/item/433-federal-executive-council-approves-draftcopyright-bill-2017

Oguamanam, C. (2011). Beyond 'Nollywood' and piracy: In search of an IP policy for Nigeria. NLALS Journal of Intellectual Property (NJIP), 1, 3-37.

Okediji, R. L. (2006).The international copyright system: Limitations, exceptions and public interest considerations for developing countries. Issue Paper No. 15. UNCTADICTSD Project on IPRs and Sustainable Development. Retrieved from http:// www.iprsonline.org/unctadictsd/docs/ruth\%202405.pdf

Ola, K. (2015). Evolution and future trends of copyright in Nigeria. In B. Fitzgerald, \& J. Gilchrist (Eds.), Copyright perspectives: Past, present and prospect (pp. 97-124). Basel: Springer International. https://doi.org/10.1007/978-3-319-15913-3 7

Olibie, E. I., Nwabunwanne, C., \& Ezenwanne, D. N. (2013). Teachers' improvisation of instructional materials for Nigerian home economics curriculum delivery: Challenges and strategies. International Journal of Adult Vocational Education and Technology, 4(4), 74-83. https://doi.org/10.4018/ijavet.2013100105

Olojo, O. J., Adewunmi, M. G., \& Ajisola, K.T. (2012). E-learning and its effects on teaching and learning in a global age. International Journal of Academic Research in Business and Social Sciences 2(1), 203-210.

Onwurah, C. U., \& Chiaha, G. T. U. (2007). Open university and distant learning: A panacea to enhanced access to higher education. In J. B. Babalola, G. O. Akpa, A. O. Ayeni, \& S. O Adedeji (Eds.), Access, equity and quality in higher education (pp. 109-120). Nigerian Association for Educational Administration and Planning (NAEAP).

Oye, N. D., Salleh, M., \& Iahad, N. A. (2011). Challenges of e-learning in Nigerian university education based on the experience of developed countries. International Journal of Managing Information Technology (IJMIT), 3(2), 39-48. https://doi.org/10.5121/ ijmit.2011.3204 
Rens, A., Prabhala, A., \& Kawooya, D. (2006). Intellectual property, education and access to knowledge in Southern Africa. ICTSD, UNCTAD and TRALAC. https://www. iprsonline.org/unctadictsd/docs/06\%2005\%2031\%20tralac\%20amended-pdf.pdf

Rosati, E. (2013). Copyright issues facing early stages of digitization projects. Cambridge Digital Humanities Network, Cambridge University.

Samuelson, P. (2017). Justifications for copyright limitations and exceptions. In R. L. Okediji (Ed.), Copyright law in an age of limitations and exceptions (pp. 12-59). Cambridge, UK: Cambridge University Press. https://doi.org/10.1017/9781316450901.003

Shaver, L. (2014). Copyright and inequality. Washington University Law Review, 92(1), 117168. https://doi.org/10.31228/osf.io/gbr8s

Solanke, O. (2014). Proposed amendments for consideration in the review of the copyright and trademarks protection for the digital environment in Nigeria. Master of Law thesis, University of Cape Town.

Standeford, D. (2015, November 22). Nigeria prepares to revamp its copyright system for the digital age. Intellectual Property Watch. Retrieved from http://www.ip-watch. org/2015/11/22/nigeria-prepares-to-revamp-its-copyright-system-for-the-digitalage/

Tang, G. H. (2011). Copyright and the public interest in China. Cheltenham, UK: Edward Elgar.

Thakrar, J., Wolfenden, F., \& Zinn, D. (2009). Harnessing open education resources to the challenges of teacher education in Sub-Saharan Africa. International Review of Research in Open and Distance Learning, 10(4), 1-15.

http://dx.doi.org/10.19173/irrodl.v10i4.705

Trucano, M. (2013, September 30). A few myths and misconceptions about digital teaching and learning materials in Africa. World Bank. [Blog post.] Retrieved from http:// blogs.worldbank.org/edutech/myths-digital-materials-africa

UK Government. (2014). Government takes important step towards modifying copyright. Retrieved from https://www.gov.uk/government/news/government-takesimportant-step-towards-modernising-copyright

Umo, U. C. (2013). Education for all: Problems and prospects in Nigeria. Journal of Resourcefulness and Distinction, 6(1), 1-15.

UN. (2011). The Millennium Development Goals report. Retrieved from http://www.un.org/ millenniumgoals/reports.shtml

UN Conference on Trade and Development. (2010). Development dimensions of intellectual property in Uganda: Transfer of technology, access to medicines and textbooks. Retrieved from http://unctad.org/en/docs/diaepcb200913overview en.pdf

UN Educational, Scientific and Cultural Organisation (UNESCO). (2017). The global education 2030 agenda: Education for Sustainable Development Goals learning objectives. Paris. Retrieved from http://unesdoc.unesco.org/images/0024/002474/247444e.pdf

UNESCO. (2000). The Dakar framework for action: Education for all: Meeting our collective commitments.Adopted by the World Education Forum, Dakar, 26-28 April. Retrieved from http://unesdoc.unesco.org/images/0012/001211/121147e.pdf 
UNESCO. (2005).Jakarta declaration. Adopted by the International Conference on the Right to Basic Education as a Fundamental Human Right and the Legal Framework for its Financing, Jakarta, 2-4 December.

UNESCO. (2016). Learning for all: Guidelines on the inclusion of learners with disabilities in open and distance learning. Paris. Retrieved from http://unesdoc.unesco.org/ images/0024/002443/244355e.pdf

UNESCO, \& UN Children's Fund (UNICEF) (2013). Making education a priority of the post-2015 development agenda. Report of the Global Thematic Consultation on Education in the Post-2015 Development Agenda. Paris and New York.

White, B. (2012, August). Guaranteeing access to knowledge: The role of libraries. WIPO Magazine. Retrieved from http://www.wipo.int/wipo magazine/en/2012/04/ article 0004.html 